Volume-VI, Number-01, January-June, 2011

\title{
Effects of Working Capital Management and Liquidity: Evidence from the Cement Industry of Bangladesh
}

\author{
SAYEDA TAHMINA QUAYYUM*
}

\begin{abstract}
This paper is an attempt to investigate the effects of working capital management efficiency as well as maintaining liquidity on the profitability of corporations. For this purpose, corporations enlisted with the cement industry of Dhaka Stock Exchange have been selected and the analysis covers a time period from year 2005 to 2009. The purpose of this paper is to establish a relationship which is statistically significant, the other purpose is to help explain the necessity of firms optimizing their level of working capital management and maintaining enough liquidity as it affects the profitability. The result of this study clearly shows significant level of relationship between the profitability indices and various liquidity indices as well as working capital components.
\end{abstract}

KEY WORDS: Working capital management, Liquidity, Cement Industry, Cash Conversion Cycle, Inventory Turnover, Receivables Turnover, Payable Turnover.

\section{INTRODUCTION}

Capital structure and working capital management are two very widely revisited area by academicians (Lazaridis and Tryfonidis,2006). This area of finance has been approached in various ways by many academicians in many countries over the world. Some has focused mainly on optimizing accounts receivable management so that the firms can maximize profit, as we see

In Besley, Scott and Meyer (1987),. The theoretical importance of the working capital components over the profitability ratio is very clear, that the lesser the time a firm needs to realize cash from its customers relative to the time it requires to pay off its creditors the better it is for its liquidity position and thus reduces the risk of dependency on external and more expensive sources of capital. For the purpose to check the practical application of the theory, an attempt to study the working capital practice in Bangladesh has been made. The idea of this particular study is similarly based on the idea of the research

*Lecturer, School of Business, United International University, Dhaka. 
conducted by Lazaridis and Tryfonidis (2006) in Greece. This study is to measure the extent of dependency of profitability over working capital components for Bangladesh context.

\section{LITERATURE REVIEW}

The attention of academicians and managers over optimizing working capital components is not very new, rather, many have provided with a variety of thoughts for the welfare of businesses over many years. For over 25 years ago, Largay and Stickney (1980, p. 53) had reported the importance of cash position for sustainability of the firm. Lazaridis and Tryfonidis (2006), had found a relationship between working capital management efficiency and profitability and so did Shin and Soenen (1998), Deloof (2003) and many others. Thus it was obvious that the firms would have to suffer if it does not take steps to minimize their dependency on external sources of funds.

According to Deloof (2003) the way that working capital is managed has a significant impact on profitability of firms. It has also been proved that by minimizing the amount of funds tied up in current assets; firms can reduce financing costs and/or increase the funds available for expansion. Summers and Wilson (2000) report that in the UK corporate sector more than $80 \%$ of daily business transactions are on credit terms. Cote and Latham (1999, p. 261) argued the management of receivables, inventory and accounts payable have tremendous impact on cash flows, which in turn affect the profitability of firms. As found by Lazaridis and Tryfonidis (2006), companies enjoy better pricing when they hold enough cash to purchase from own suppliers and thus they may enhance their profit. So having enough liquidity also affects the profitability of the firm.

As found by Long, Malitz and Ravid (1993) it is seen that liberal credit terms to the customers increase the sales level of the firm, though having a continuous trouble with managing short term financing in the finance department. But extensive use of liberal credit terms to customers reduces the profitability of the firm. It is up to the firm depending on its nature of business to decide whether to choose liberal credit terms to enhance marketing to the customers or to focus on profitability of the firm with minimizing its cash conversion cycle and optimize level of cash holdings.

Moyer, Mcguigan and Kretlow (1995, p. 11) found that WC consists of a large portion of a firm's total investment in assets, 40 percent in manufacturing and 50\% - 60\% in retailing and wholesale industries respectively. Scherr (1989, p. 16) claimed that by implementing best practices in WC, companies can strengthen strong cash flow levels, improve profitability, budgeting and forecasting process. 
As stated by Siddiquee and Khan (2009), it has been observed that, firms which are better at managing working capital are found to be able to make counter cyclical moves to build competitive advantage. They are also better at generating fund internally and also face lesser trouble while seeking external sources of financing.

It is also consistent with this study, as this study also found to have significant level of positive relationship between better management of working capital and high profitability.

\section{DATA COLLECTION, VARIABLES AND METHODOLOGY}

\section{Data Collection}

For the purpose of this study, secondary data have been collected and the data collected were from listed firms in the Dhaka Stock Exchange. The reason for choosing this source is primarily due to the better reliability of the financial statements. Due to time constraint, only cement industry has been selected for the said research. The industry consists of five companies, due to unavailability of one company all years secondary data, four companies were taken as sample; this covers $80 \%$ of the population. The outliers had been adjusted to get better reliable result. The duration covered in this study was from year 2005 to year 2009 for this analysis. Finally the financial statements were obtained from the Dhaka Stock Exchange Library.

\section{Methodology and Variables}

As mentioned earlier this research idea is based on the work done by Lazaridis and Tryfonidis (2006). The methodology of this study is to find out the dependency of profitability ratios over many other working capital components and liquidity positions. To cover the liquidity position, few cash position ratios have been considered along with traditional liquidity ratios. And for the purpose of the analysis, regression has been conducted.

So the basic model for the study that has been followed is,

Profitability of the Firm $=f$ (Quick Ratio , Cash Conversion Cycle , Receivables Collection Period (RCP), Payable Deferral Period , Inventory Turnover Period, Cash to Current Liability , Cash to Sales )

The measure of working capital management is cash conversion cycle. And it is described by the following equation:

Cash conversion cycle $=$ Receivables collection period + Inventory turnover period-Payable deferral period 
For the purpose of analysis, the ultimate measurement of profitability has been chosen to be return on asset (ROA). The method of calculating cash conversion cycle (CCC) has been shown earlier as well. The variables are calculated as shown in the table following. Only the CCC and its components have a unit of days, except for these, all other variables are expressed in terms of proportion or ratio. The variables that have been used are as follows:

\begin{tabular}{c|l|l}
\hline No & \multicolumn{1}{c}{ Variables } & \multicolumn{1}{c}{ Method used for Calculation } \\
\hline 1 & Return On Asset (ROA) & Net Profit / Total Asset \\
2 & Net Profit Margin (NPM) & Net Profit / Sales \\
3 & Interest Coverage Ratio (ICR) & $\begin{array}{l}\text { Earnings Before Interest and } \\
\text { Taxes/Interest Expense } \\
\text { (Current Asset - Inventory)/Current }\end{array}$ \\
4 & Quick Ratio (QR) & Liability \\
5 & Cash Conversion Cycle (CCC) & RCP + PDP - ITP \\
6 & Receivables Collection Period (RCP) & 360 / (Sales/ Accounts Receivables) \\
7 & Payable Deferral Period (PDP) & $360 /$ (COGS/Accounts Payable) \\
8 & Inventory Turnover Period (ITP) & $360 /$ (COGS/Inventory) \\
9 & Cash to Current Liability ( CTCL) & Cash/Current Liability \\
10 & Cash to Sales (CTS) & Cash/Sales \\
\hline
\end{tabular}

The ratio of cash to sales has been taken to have an idea if the companies are enjoying any benefit out of holding cash which reflects in the company's profitability. As it has been explained as a probable reason by Lazaridis and Tryfonidis (2006) that companies enjoy better pricing when they hold enough cash to purchase from own suppliers. Cash to current liability has been taken to observe if the companies are cautious enough to keep up with their maturing dues or obligations and if they are benefitting out of this performance as well.

Many other variables have also been considered for the purpose of this study, but those have been excluded later as they do not show statistically significant relationship with the dependent variables. Finally the dependent variables used for the research are mainly the profitability ratios and debt coverage ratio or ROA, NPM and ICR respectively. But NPM and ICR has also been used as independent variable to assess their impact on ROA.

All other variables are considered to disclose the working capital condition or cash position of the firm and are used as independent variable against the earlier said dependent variables. 


\section{ANALYSIS AND FINDINGS}

\section{Descriptive Statistics}

The following table gives the descriptive statistics of the collected variables. The mean and median of net profit margin are very close to that of ROA, Which means in most of the years these firms had a total asset turnover of 1 . The CCC shows that, it takes the firm's around 93 days on average (Median 113) to realize net cash on selling of a particular good. While they paid their creditors prior to receiving the sales proceed. Inventory takes on an average 58 days to get sold (median 33 days). There is a scope to handle CCC with more efficiency.

TABLE 1

\section{DESCRIPTIVE STATISTICS OF PROFITABILITY RATIOS AND} WORKING CAPITAL RATIOS

\begin{tabular}{ccccccc}
\hline & Mean & Median & $\begin{array}{c}\text { Standard } \\
\text { Deviation }\end{array}$ & $\begin{array}{c}\text { Standard } \\
\text { Error }\end{array}$ & $\begin{array}{c}\text { Confidence } \\
\text { Level (95\%) }\end{array}$ \\
\hline ROA & 0.05595 & 0.04416 & 0.04667 & 0.01205 & 0.02585 \\
NPM & 0.05498 & 0.04327 & 0.04356 & 0.01125 & 0.02412 \\
ICR & 7.79891 & 2.15969 & 13.62266 & 3.51736 & 7.54398 \\
QR & 0.33437 & 0.47942 & 0.91545 & 0.23637 & 0.50696 \\
CCC & 92.46761 & 112.79765 & 62.67980 & 16.18385 & 34.71092 \\
ITR & 57.58620 & 32.30887 & 57.01169 & 14.72036 & 31.57202 \\
CTCL & 0.17508 & 0.07436 & 0.27587 & 0.07123 & 0.15277 \\
CTS & 0.05676 & 0.02792 & 0.06746 & 0.01742 & 0.03736 \\
\hline
\end{tabular}

In the following table 2 Pearson correlations for the variables have been shown. We can see that the return on asset, net profit margin and interest coverage ratio all are negatively correlated with the cash conversion cycle, which indicate that more profitable firms either delay their payment towards their suppliers-creditors or accelerate their receivables.. These results are consistent with the view that the shorter the period between production and sale of products the larger is the firm's profitability. It is understandable that companies with cash in hand can purchase raw materials from suppliers with better prices and also may take benefit in many other bargaining. Maybe that is the reason of cash to sales and cash to current liability are both having very high positive correlation with interest coverage ratio. It is in line with the observation of Lazaridis and Tryfonidis (2006). 


\section{CORRELATION BETWEEN PROFITABILITY RATIOS} AND WORKING CAPITAL RATIOS

\begin{tabular}{|c|c|c|c|c|c|c|c|c|}
\hline & $R O A$ & $N P M$ & $I C R$ & $Q R$ & CCC & $I T R$ & CTCL & CTS \\
\hline ROA & 1.0000 & & & & & & & \\
\hline NPM & 0.9178 & 1.0000 & & & & & & \\
\hline ICR & 0.6978 & 0.7102 & 1.0000 & & & & & \\
\hline QR & 0.6837 & 0.5037 & 0.4923 & 1.0000 & & & & \\
\hline CCC & -0.7247 & -0.5838 & -0.5233 & -0.4565 & 1.0000 & & & \\
\hline ITR & 0.8341 & 0.7309 & 0.6061 & 0.5067 & -0.9246 & 1.0000 & & \\
\hline CTCL & 0.6699 & 0.5493 & 0.9101 & 0.5746 & -0.5814 & 0.6489 & 1.0000 & \\
\hline CTS & 0.6982 & 0.5843 & 0.8351 & 0.5616 & -0.6105 & 0.6996 & 0.9676 & 1.0000 \\
\hline
\end{tabular}

\section{Regression Analysis}

As we have seen from the correlation table shown previously we get an idea about the relationship nature between variables but to analyze the extent of dependency of firms' profitability on its working capital management, regression analysis has been conducted. In this study the working capital components and cash position indicators are the independent variables as said earlier.

This study has focused on simple regression and multiple regressions both. In the first section, the single regression has been conducted over each individual dependent variable, i.e., ROA, NPM and ICR. The Second section covers the Multiple Regression model.

\section{Section 1: Single Regression}

In the Appendix Table-A, we see the result of single regression conducted for ROA against 7 independent variables. The regression was also conducted against few other variables as mentioned previously, but had to be excluded later due to lack of statistical significance, for example, the receivables collection period and the payable deferral period, the current ratio etc. But current ratio when adjusted for inventory and converted to quick ratio shows a significantly higher level of influence over the profitability ratios with much more reliability, this will be shown in the following parts of the study. And total debt to total asset although showed a positive correlation of over 0.45 with CCC but the value was not statistically significant when regression conducted.

We can see from the Appendix A Table - (i), that all the results have a very dependable level of $\mathrm{P}$ Values. For better performance of ROA, the most important independent variable is NPM which is very easily understandable. But the purpose of the study is to assess the importance of Working Capital management. And we see that CCC has a negative effect on the ROA, and almost 
$53 \%$ of the change in ROA can be explained with the change in CCC. This is quite a good level of explanatory power, as we know that for cross section data a level of $55 \%$ of $\mathrm{R}$ Square is quite good. Among the components of CCC, inventory turnover ratio has an explanatory power of $70 \%$ over the change in ROA. The regression equations derived from the study are:

$$
\begin{aligned}
& \text { Model }(a): R O A=0.105845-0.00054 * C C C \\
& \text { Model }(b): R O A=0.044295+0.034855 * Q R \\
& \text { Model }(c): R O A=0.001883+0.98336 * N P M \\
& \text { Model }(d): R O A=0.037304+0.002391 * I C R \\
& \text { Model }(e): R O A=0.016628-0.00683 * I T P \\
& \text { Model }(f): R O A=0.036105+0.11331 * C T C L \\
& \text { Model }(g): R O A=0.0285311+0.483034 * C T S
\end{aligned}
$$

From the derived equations we see that, cash to current liability and cash to sales exert very high level of influence on the ROA. Especially if we look at model (g), the derived equation asserts that firms should focus on projecting their future sales and hold cash as according to that, so that they can maximize their level of ROA. The constraint faced by the firms in such a situation would be the limitation of their cash financing capability and affordability of that financing.

The single regression for net profit margin (NPM) shows result as following:

$$
\begin{aligned}
& \text { Model }(h): N P M=0.092494-0.00041 * C C C \\
& \text { Model }(i): N P M=0.046968+0.023966 * Q R \\
& \text { Model }(j): N P M=0.037271+0.002271 * I C R \\
& \text { Model }(k): N P M=0.02282142-0.0005585 * I T P \\
& \text { Model }(l): N P M=0.039795+0.086736 * C T C L \\
& \text { Model }(m): N P M=0.033566+0.377284 * C T S
\end{aligned}
$$

From the resulting equations above we see that, for better performance of NPM, the most capable independent variable of explaining the change is inventory turnover period with an R Square of 0.534255 as we would see in Appendix- A, Table - (ii); it might be due to the profit margin of firms increasing with increasing demand of the product with a given level of fixed costs and lesser elastic costs. The CCC has a negative effect on the NPM, and almost $34.08 \%$ of the change in NPM can be explained with the change in CCC. Another important independent variable is interest coverage ratio. Almost $50.4376 \%$ of the change in NPM can be explained with the change in interest coverage ratio or ICR.

From the derived equations we again see that cash to sales exerts a very high level of influence on the NPM. So, mathematically, the derived equation asserts 
that firms should focus on forecasting their future sales and hold cash as according to that, so that they can maximize their level of NPM as well. The constraint faced by individual firms in such a situation would again be the limitation of individual firms' cash financing capability and affordability of that financing.

This regression equation is consistent with the findings of many other studies over the world including Lazaridis and Tryfonidis (2006) that a decrease in the cash conversion cycle will generate more profits for a company.

In order to have an idea whether a firm managing its working capital efficiently enjoys any support in debt paying, a further test has been conducted. Considering interest coverage ratio as for the dependent variable and cash conversion cycle as independent variable the following result has been derived.

TABLE 3

SINGLE REGRESSION ANALYSIS FOR CEMENT INDUSTRY IN DSE

\begin{tabular}{c|c|c|c|c|c|c}
\hline $\begin{array}{c}\text { Dependent } \\
\text { Variable }\end{array}$ & $\begin{array}{c}\text { Independent } \\
\text { Variable }\end{array}$ & R Square & $\begin{array}{c}\text { Adjusted R } \\
\text { Square }\end{array}$ & Coefficient & T-Stat & P Value \\
\hline ICR & CCC & 0.273861 & 0.218004 & -0.113740 & -2.2143 & 0.04530 \\
\hline
\end{tabular}

The result shows a negative relationship with a coefficient of -0.113740 though the $\mathrm{R}$ Square is quite less. So, there is a negative relationship between ICR and CCC. This result is highly significant and does make economic sense, since the longer a firm delays its payments the higher level of working capital levels it reserves and uses in order to increase profitability, this is also consistent with the finding of Lazaridis and Tryfonidis (2006).

\section{Section 2: Multiple Regressions}

A multiple regression shows the influence of multiple independent variables on a single dependent variable. In order to avoid redundancy effect on multiple regressions, few variables from the earlier said selected ones have been eliminated. For instance, inventory turnover ratio, receivables turnover period, and payable deferral period they underlie within the cash conversion cycle. Cash positions ratios are a part of quick ratio, NPM results out of interest coverage ratio so cash position and NPM have been eliminated.

$$
\begin{array}{llcc}
\text { Model }- \text { O: } \text { ROA }= & 0.069178-0.0003 \text { CCC }+0.001092 \text { ICR }+0.017523 \text { QR } \\
\text { Standard Error } & 0.000137 & 0.000646 & 0.009202
\end{array}
$$

The analysis has been done against cash conversion cycle, quick ratio and interest coverage ratio. In the above shown Model - $\mathrm{O}$, we see that cash conversion cycle is having a negative relation with the ROA and the coefficient 
is -0.0003 , this equation is very highly dependable as the $\mathrm{P}$ Value is only 0.001277 as we see in Appendix -B. The explanatory power of the equation for a change in the ROA is also very high. Given that is a cross section data evaluation; an R Square of 0.748 is very good. The dominant influential factor over the ROA is quick ratio, which is a measure of liquidity of the firm; this means the firms which are better at handling its liquidity as opposed to its current dues are better at optimizing their use of assets and generating more profit. This makes sense, as the firms which make the best use out of their liquid assets and its financing are more likely to generate better production level and profitability.

\section{CONCLUSIONS AND RECOMMENDATIONS}

This study finds a negative relationship between cash conversion cycle and profitability of the Firm. This complies with the finding of Shin and Soenen (1998) and Lazaridis and Tryfonidis (2006) and many others. This study extends the earlier said studies in the sense that this study shows a strong positive relationship of profitability with the firms' cash holding position along with other indicators. And it also recommends that the firms should forecast their sales and hold cash enough as according to their projected sales level, so that they be able to take advantage of the bargaining position while making purchases and thus reduce cost. It is very clear that the efficient management of working capital and liquidity has a positive effect on the firms' profitability. So this study clearly asserts that, firms in the cement industry in Bangladesh have enough scope to enhance their profitability by handling their working capital in more efficient ways. Especially, the inventory turnover if handled efficiently can produce a significant positive impact on profitability of the firm.

Thus this study finds enough evidences that a firm is likely to enjoy better profitability if the firm manages its working capital with better efficiency and focuses on cash position with more care.

\section{REFERENCES}

Besley, Scott, \& Meyer, R.L (1987). An Empirical Investigation of Factors Affecting the Cash Conversion Cycle. Annual Meeting of the Financial Management Association, Las Vegas Nevada.

Cote, J. M., \& Latham, C. K.. (1999). The Merchandising Ratio: A Comprehensive Measure of Working Capital Strategy. Issues in Accounting Education, 14(2), 255267.

Deloof, M. (2003). Does Working Capital Management Affect Profitability of Belgian Firms?. Journal of Business Finance \& Accounting, 30 (3\& 4), p. 585.

Largay, J., \& Stickney, C. (1980). Cash Flows, Ratio Analysis and the W. T. Grant Company Bankruptcy. Financial Analyst Journal, pp. 51-54 12. 
Lazaridis, I., Tryfonidis, D. (2005). The relationship between working capital management and profitability of listed companies in the Athens Stock Exchange. SSRN.com.

[Online Available] http://papers.ssrn.com/sol3/papers.cfm?abstract id=931591

Long, M.S., Malitz, I.B., \& Ravid, S.A (1993). Trade Credit, Quality Guarantees, and Product Marketability. Financial Management, 22(4), 117-127.

Moyer R. C., Mcguigan J. R., Kretlow W. J. (1995). Contemporary Financial Management, West Publishing Co, Cincinati, Ohio.

Pike R., Nam, S. C. (2001). Credit Management: An Examination of Policy Choices, Practices and Late Payment in UK Companies. Journal of Business Finance \& Accounting, l 28(78),1013.

Raheman, A., Nasr, M. (2007). Working Capital Management And Profitability - Case Of Pakistani Firms. International Review of Business Research papers, 3(1), 279 300.

Scherr, F. C. (1989). Modern Working Capital Management, Text and Cases. Englewood Cliffs, New Jersey: Prentice-Hall International Editions.

Shin, H. H, Soenen, L. (1998). Efficiency of Working Capital Management and Corporate Profitability, Financial Practice and Education, 8(2),37-45.

Siddiquee, M. M., \& Khan, S. M. (2008). Analyzing Working Capital Performance: Evidence from Dhaka Stock Exchange (DSE) Ltd. The Journal of Nepalese Business Studies, III( 1).

Summers B., Wilson, N. (2000). Trade Credit Management and the Decision to Use Factoring: An Empirical Study. Journal of Business Finance \& Accounting, 27 (1\&2), 37- 68.

Van Horne, J. C. \& Wachowicz, J. M. 2000. Fundamentals of Financial Management, 11th Ed. Prentice Hall Inc.

Wilner, B. (2000). The Exploitation of Relationships in Financial Distress: The Case of Trade Credit. The Journal of Finance, 55(1), 153. 


\section{APPENDIX - A}

Single Regression Results of Dependent Variables:

TABLE (I)

SINGLE REGRESSION ANALYSIS FOR ROA OF CEMENT INDUSTRY IN DSE

\begin{tabular}{ccccccc|c|c|c}
\hline $\begin{array}{c}\text { Dependent } \\
\text { Variable }\end{array}$ & $\begin{array}{c}\text { Independent } \\
\text { Variables }\end{array}$ & R Square & $\begin{array}{c}\text { Adjusted } \\
\text { R Square }\end{array}$ & Coefficient & T-Stat & P Value & $\begin{array}{c}\text { Standard } \\
\text { Error }\end{array}$ \\
\hline ROA & CCC & 0.525156 & 0.488629 & -0.000540 & -3.7918 & 0.00224 & 0.0334 \\
ROA & QR & 0.467407 & 0.426438 & 0.034855 & 3.37770 & 0.00495 & 0.0354 \\
ROA & NPM & 0.842342 & 0.830215 & 0.983360 & 8.33409 & 0.00000 & 0.0192 \\
ROA & ITP & 0.695719 & 0.672313 & 0.000683 & 5.45194 & 0.00011 & 0.0267 \\
ROA & ICR & 0.486943 & 0.447477 & 0.002391 & 3.51259 & 0.00382 & 0.0347 \\
ROA & CTCL & 0.448827 & 0.406430 & 0.113341 & 3.25363 & 0.00629 & 0.0359 \\
ROA & CTS & 0.487479 & 0.448054 & 0.483034 & 3.51636 & 0.00379 & 0.0347 \\
\hline
\end{tabular}

TABLE (II)

SINGLE REGRESSION ANALYSIS FOR NPM OF CEMENT INDUSTRY IN DSE

\begin{tabular}{c|c|c|l|c|l|l|l}
\hline $\begin{array}{l}\text { Dependent } \\
\text { Variable }\end{array}$ & $\begin{array}{l}\text { Independent } \\
\text { Variables }\end{array}$ & R Square & $\begin{array}{l}\text { Adjusted R } \\
\text { Square }\end{array}$ & Coefficient & T-Stat & P Value & $\begin{array}{l}\text { Standard } \\
\text { Error }\end{array}$ \\
\hline NPM & CCC & 0.340767 & 0.290057 & -0.000410 & -2.59228 & 0.022331 & 0.0367 \\
NPM & QR & 0.253677 & 0.196267 & 0.023966 & 2.102077 & 0.055603 & 0.0239 \\
NPM & ITP & 0.534255 & 0.498429 & 0.000558 & 3.861643 & 0.001964 & 0.0309 \\
NPM & ICR & 0.504376 & 0.466251 & 0.002271 & 3.637249 & 0.003010 & 0.0318 \\
NPM & CTS & 0.341409 & 0.290748 & 0.377284 & 2.595979 & 0.022174 & 0.0367 \\
NPM & CTCL & 0.301749 & 0.248038 & 0.086736 & 2.370223 & 0.033922 & 0.0378 \\
\hline
\end{tabular}

APPENDIX - B

Multiple Regression Result for Dependant Variable:

TABLE (I)

MULTIPLE REGRESSION ANALYSIS FOR CEMENT INDUSTRY IN DSE.

\begin{tabular}{c|c|c|c|c|c}
\hline $\begin{array}{c}\text { Dependent } \\
\text { Variable }\end{array}$ & Independent Variables & Coefficient & R Square & Significance F & Standard Error \\
\hline ROA & CCC & 0.0003 & 0.74800 & 0.00128 & 0.02643 \\
ROA & ICR & 0.001092 & & \\
ROA & QR & 0.017523 & & \\
\hline
\end{tabular}

